\title{
Genetic association of $A P O B$ polymorphisms with variation in serum lipid profile among the Kuwait population
}

\author{
Suzanne A Al-Bustan ${ }^{1 *}$, Majed A Alnaqeeb ${ }^{1}$, Babitha G Annice ${ }^{1}$, Ghada A Ebrahim² ${ }^{2}$ and Thanaa M Refai ${ }^{3}$
}

\begin{abstract}
Background: Several studies have identified $A P O B$ as a candidate gene predisposing individuals to dyslipidemia. Polymorphisms including the signal peptide (rs11279109), codon 2488 Xbal (rs1042031), codon 3611 Mspl (rs693), codon 4154 EcoRI (rs1801701) and the 3' variable number of tandem repeats have been reported to be associated with dyslipidemia in several populations. With limited studies on Arabs, this study aimed to investigate the genetic association of $A P O B$ polymorphisms and assess the potential influence of minor and rare alleles on serum lipid levels in the Kuwaiti population.
\end{abstract}

Methods: A total of 795 Kuwaiti subjects, documented with phenotypic data and fasting serum lipid levels, were genotyped for the five polymorphisms using PCR, PCR-RFLP and gene fragment analysis. Genotype and allele association with variation in serum lipid levels as well as haplotypes were analyzed using chi-square test, univariate and logistic regression analysis.

Results: Analysis of the genotype and allele frequencies distribution revealed a significant positive association between the $A P O B$ signal peptide and $3611 \mathrm{Mspl}$ polymorphisms with increased levels of triglycerides (statistical power of 80\%). Haplotype analysis further supported the findings by showing that carriers of haplotypes $\left(\mathrm{IX}^{-} \mathrm{M}^{-} \mathrm{E}^{+} \mathrm{M}\right)$ had significantly lower mean (SD) TG levels $(0.86 \pm 0.07)$ as compared to non-carriers (1.01 \pm 0.02$)$. Significance was also observed with regards to positive family history of hypercholesterolemia.

Conclusion: The results imply a "protective role" for two alleles (rs11279109 and rs1801701) in which logistic regression analysis showed a significant half-fold decrease in the risk for heterozygotes of rs11279109 and an 8.8 fold decrease in the risk for homozygous $\mathrm{M}^{-} \mathrm{M}^{-}$of $\mathrm{rs} 1801701$ of having lower TG levels $(<1.70 \mathrm{mmol} / \mathrm{L})$ in individuals. This suggests that genetic interaction between various polymorphisms at different gene loci act in linkage disequilibrium to affect serum TG levels. Apo B genotyping may be a useful adjunct for the identification of individuals at risk of developing dyslipidemia in order to provide them with lifestyle modifications and/or pharmacological intervention to mitigate the effects of gene interaction and environmental influence.

Keywords: APOB, SNPs, VNTR, Genetic polymorphisms, Dyslipidemia, Genetic association, Arab, Kuwait

\footnotetext{
* Correspondence: s.albustan@ku.edu.kw

'Department of Biological Sciences, Faculty of Science, Kuwait University, PO Box 5969, SAFAT, 13060 Kuwait City, Kuwait

Full list of author information is available at the end of the article
} 


\section{Background}

The diet of Kuwaitis, majority of who are of Arab ethnicity, is relatively high in fat. The life style adopted by many Kuwaitis is thought to cause an increase in the levels of plasma lipids that may lead to an increase in risk factors leading to heart disease. The incidence of hypercholesterolemia was reported to be higher in women $(36.6 \%)$ than in men $(30.2 \%)$ while hypertriglyceridemia (HTG) was found to be higher in men (44.1\%) than in women (33.8\%) [1]. It has also been reported that the Kuwaiti population has one of the highest frequencies for overweight (80.4\%), obesity (47.5\%) and metabolic syndrome (36.2\%) [2]. Several studies have attempted to elucidate the genetic and molecular mechanisms of dyslipidemia using measurements of plasma lipids and have identified a number of candidate genes and pathways relevant to lipid metabolism and/or transport [3-5]. In addition, several genome-wide association studies (GWAS) have established genetic association between variation in plasma lipid levels [6-8] with various gene loci being directly or indirectly involved in lipid metabolism and/or transport. In one GWAS study, a population case-control design that evaluated 1700 subjects at the extremes of lipid level phenotypes reported a significant association with the apolipoprotein $B$ gene locus $(A P O B)$ as well as a significant accumulation of rare variants as defined by a minor allele frequency of $<1 \%$ in controls [9].

The apoB protein forms the integral part of chylomicrons and VLDL synthesized during lipoprotein metabolism. The apoB-100 is a single polypeptide chain of 4,560-4,563-amino acids including a 27 residue signal sequence [10]. The mature protein contains the binding site for the uptake of LDL by the LDL receptor. The protein is coded by a 43 Kilo-base gene comprising 29 exons and 28 introns $[11,12]$. There are several polymorphisms at the $A P O B$ gene locus [13-15]. These include a common polymorphism (rs11279109) in the promoter region coding for the signal peptide. The deletion allele (sp24, D) codes for the 24-amino acid signal peptide that lacks the hydrophobic leucine-alanine-leucine residues affecting protein hydrophobicity [16,17], and has been shown to be associated with dyslipidemia, body mass index (BMI) and other phenotypes [18-22]. Other common polymorphisms are found in the coding sequences of exon 26, spanning $7572 \mathrm{bp}$ [12] including a single nucleotide polymorphism (SNP) in the consensus sequence of the receptor-binding region [15] that can affect the binding affinity of the ligand to the LDL receptor [15,23]. SNPs, including codons 3611 (rs693) and 4154 (rs1801701), result in amino acid substitution of glutamine to arginine and glutamic acid to lysine, respectively. These SNPs have been shown to be associated with variation in total cholesterol (TC) and low density lipoprotein- cholesterol (LDL-C) levels [20,22,24,25]. In addition, another commonly studied polymorphism is found in the $A P O B$ gene in exon 29 (rs1042031) involves a silent mutation from cytosine to thymine in the third base of codon 2488 and has been reported to be associated with dyslipidemia $[20,22,23,25]$. Finally, a variable number of tandem repeats (VNTR) at the 3' end, located about 75 bp downstream the second polyadenylation signal [13] consisting of a dimeric 15 bp AT repeat unit $[9,14,26]$, has been suggested to influence polyadenylation and processing of the mRNA transcript of apoB-100 [13].

The allele and genotype frequencies at the $A P O B$ gene locus have been studied and reported for numerous populations including Northern Europeans [27-29], Southern Europeans [19,29,30], Asians [22,25,31,32] and others [33-36]. However, no such frequencies have ever been reported for the Kuwaiti population. Furthermore there are very few publications on the allele frequencies of the $A P O B$ polymorphisms in other Arab and Gulf region countries [21]. Generally, there has been very little data published on the genetic population structure of the Kuwaiti population [37-39]. Therefore the objective of this study was to investigate the genetic association of $A P O B$ polymorphisms with variation in lipid levels in the Kuwaiti population and to assess the potential influence of the minor and rare alleles on serum lipid levels. The Kuwaiti population is generally heterogeneous comprising two major ethnic groups, Arabs including Bedouin Arabs, and Persians, while the rest are an admix of both as well as other minor ethnic groups [38]. There are no previous studies on $A P O B$ polymorphisms in an Arab population at the $A P O B$ gene loci or with the association of the signal peptide, MspI and EcoRI polymorphisms with variation in serum lipid levels.

\section{Subjects and methods Sample description}

Fasting blood samples were collected from a total of 795 healthy Kuwaiti volunteers whose informed consent for the purpose of the study was obtained. The study was reviewed and approved by the ethics committee at Kuwait University. The samples included 330 males and 465 females with ages ranging from 18 to 69 years of age and a mean of 57.1 years $( \pm 13.0 \mathrm{SD})$. The samples analyzed in this study included healthy Kuwaiti subjects undergoing routine medical checks at clinics or major hospitals in Kuwait. For each sample, phenotypic variables including BMI and family history of dyslipidemia, hypertension, diabetes and heart disease were recorded (Table 1).

\section{Biochemical analysis and diagnostic criteria}

Quantitative measurements of serum TC, triglycerides (TG), high density lipoprotein-cholesterol (HDL-C), and 
Table 1 General characteristics and serum lipid levels of the Kuwaiti population sample analyzed in this study

\begin{tabular}{|c|c|c|c|c|}
\hline & $\begin{array}{c}\text { Male } \\
(n=330)\end{array}$ & $\begin{array}{c}\text { Female } \\
(n=465)\end{array}$ & $\begin{array}{c}\text { Total } \\
(\mathrm{n}=795)\end{array}$ & $P$ value \\
\hline Age (Years) $\pm S D$ & $32.63 \pm 0.78$ & $30.62 \pm 0.66$ & $31.45 \pm 0.68$ & 0.0488 \\
\hline Body Mass Index $\left(\mathrm{kg} / \mathrm{m}^{2}\right) \pm S D$ & $27.24 \pm 0.45$ & $26.55 \pm 0.35$ & $26.80 \pm 0.40$ & 0.2264 \\
\hline Total Cholesterol $(\mathrm{mmol} / \mathrm{L}) \pm \mathrm{SD}$ & $4.71 \pm 0.06$ & $4.70 \pm 0.05$ & $4.70 \pm 0.06$ & 0.9037 \\
\hline Triglycerides $(\mathrm{mmol} / \mathrm{L}) \pm \mathrm{SD}$ & $1.28 \pm 0.05$ & $0.92 \pm 0.04$ & $1.06 \pm 0.05$ & $<0.0001$ \\
\hline $\mathrm{HDL}-\mathrm{C}(\mathrm{mmol} / \mathrm{L}) \pm \mathrm{SD}$ & $0.97 \pm 0.02$ & $1.22 \pm 0.02$ & $1.13 \pm 0.02$ & $<0.0001$ \\
\hline $\mathrm{LDL}-\mathrm{C}(\mathrm{mmol} / \mathrm{L}) \pm \mathrm{SD}$ & $3.19 \pm 0.05$ & $3.08 \pm 0.04$ & $3.12 \pm 0.05$ & 0.0837 \\
\hline Ethnicity: & n (\%) & n (\%) & & \\
\hline Arabs & $126(37.1)$ & $214(62.9)$ & 340 & 0.1452 \\
\hline Bedouin Arabs & $26(44.1)$ & $33(55.9)$ & 59 & \\
\hline Iranian & $56(42.4)$ & $76(57.6)$ & 132 & \\
\hline Heterogeneous & $122(46.2)$ & $142(53.8)$ & 264 & \\
\hline Positive Family History*: & n (\%) & n (\%) & & \\
\hline Dyslipidemia & $86(43.7)$ & $111(56.3)$ & 197 & \\
\hline Hypertension & $156(39)$ & $244(61)$ & 400 & \\
\hline Diabetes Mellitus 2 & $167(38.7)$ & $265(61.3)$ & 432 & \\
\hline Heart Disease & $73(36.0)$ & $130(64.0)$ & 203 & \\
\hline
\end{tabular}

*The numbers given is for those samples with documented family history only. Samples with undocumented history are not shown in any of the tables and were omitted from the statistical analysis and from the polymorphism association analysis.

LDL-C were determined by enzymatic methods with commercially available kits (Synchron System Reagents, Beckman Coulter, Brea, CA, USA) analyzed on a UniCel DxC 800 Synchron Clinical Systems (Beckman Coulter, USA) in the Clinical Chemistry Laboratory at Al-Amiri Hospital, Kuwait.

\section{Genotypic analysis of the $A P O B$ polymorphism}

SNPs rs11279109, rs693, rs1801701, rs1042031, 3'VNTR were screened using various molecular techniques employing the polymerase chain reaction (PCR). The RFLP sites at the $A P O B$ gene locus include codon 2488 (rs693), codon 3611 (rs1801701) and codon 4154 (rs1042031) contain XbaI, MspI and EcoRI restriction sites, respectively. Total genomic DNA was extracted from $5 \mathrm{ml}$ of whole blood using proteinase $\mathrm{K}$ digestion and salting out extraction according to the method described by Miller et al. [40]. The DNA samples were then subjected to genotyping for the five polymorphisms using different PCR-based techniques as summarized in Table 2.

\section{Genotyping the signal peptide polymorphism at the APOB gene locus}

The deletion/insertion allele at the signal peptide locus (rs11279109) was performed using PCR to amplify the target sequence (93 bp) as described by $\mathrm{Xu}$ et al. [41]. The PCR products were then analyzed by gel electrophoresis on a 4\% 3:1 Nusieve: agarose gel pre-stained with ethidium bromide $(10 \mathrm{mg} / \mathrm{ml})$. Electrophoresis was performed for one hour at $200 \mathrm{~V}$ and $100 \mathrm{~mA}$. Following electrophoresis, the bands were visualized under UV and documented using Syngene Digital Documentation system (Synoptics Ltd, Cambridge, UK). The fragment size was determined with Gene tools software (Version 4.00) by comparing the PCR product bands with those of a $123 \mathrm{bp}$ DNA ladder.

\section{Genotyping the SNPS (Xbal, Mspl and EcoRI) at the APOB Exon 26 and 29}

The genotypes for the three codons were determined by PCR-RFLP [24]. The PCR products $(10 \mu \mathrm{l})$ were digested with the XbaI, MspI and EcoRI restriction enzymes in separate reactions [23]. The products were then separated by horizontal gel electrophoresis on a 4\% 3:1 Nusieve:Agarose gel pre-stained with ethidium bromide $(10 \mathrm{mg} / \mathrm{ml})$. Following electrophoresis, the bands were visualized, documented and sized as described above. In order to ensure quality and reliability of the data obtained, randomly selected samples including all three genotypes at each locus ( $\mathrm{n}=10$ for each SNP) were randomly selected for sequencing the target region to confirm the genotypes obtained by PCR-RFLP. The region spans the SNPs at XbaI, MspI and EcoRI of the $A P O B$ gene locus. These samples were then used as positive controls in subsequent PCR-RFLP reactions. All sequences were submitted to GenBank with the following accession numbers 
Table 2 Summary of the primers and PCR-RFLP conditions used for the analysis of the APOB polymorphisms

\begin{tabular}{|c|c|c|c|c|c|}
\hline SNP (RS\#) & Primer sequence & Amplification conditions & PCR prod (bp) & RE digests & Ref \\
\hline \multirow{4}{*}{$\begin{array}{l}\text { SP Ins/Del } \\
\text { (rs11279109) }\end{array}$} & \multirow[t]{2}{*}{ 5'-CAGCTGGCGATGGACCCGCCGA-3' } & $95^{\circ} \mathrm{C} 5$ mins & \multirow[t]{4}{*}{$93 / 84$} & \multirow[t]{4}{*}{ N/A } & \multirow[t]{4}{*}{ Xu et al. [41] } \\
\hline & & $95^{\circ} \mathrm{C} 0.50 \mathrm{sec}, 65^{\circ} \mathrm{C} 1 \mathrm{~min}$ & & & \\
\hline & \multirow[t]{2}{*}{ 5'-ACCGGCCCTGGCGCCCGCCAGCA-3' } & $65^{\circ} \mathrm{C} 0.50 \mathrm{sec}$ ( 35 cycles) & & & \\
\hline & & $72^{\circ} \mathrm{C} 7$ mins, hold at $4^{\circ} \mathrm{C}$ & & & \\
\hline \multirow{4}{*}{$\begin{array}{l}\text { Codon } 2488 \\
\text { Xba1 (rs693) }\end{array}$} & 5'-GATGAAACCAATGACAAAATCC-3' & $94^{\circ} \mathrm{C} 5$ mins & \multirow[t]{4}{*}{450} & \multirow[t]{2}{*}{240} & \multirow[t]{4}{*}{ Pan et al. [31] } \\
\hline & \multirow[t]{3}{*}{ 5'-AACAGTGAACCCTTGCTCTACC-3' } & $94^{\circ} \mathrm{C} 0.30 \mathrm{sec}, 58^{\circ} \mathrm{C} 30 \mathrm{sec}$ & & & \\
\hline & & $70^{\circ} \mathrm{C} 0.30 \mathrm{sec}(40$ cycles $)$ & & \multirow[t]{2}{*}{210} & \\
\hline & & $70^{\circ} \mathrm{C} 10$ mins, hold at $4^{\circ} \mathrm{C}$ & & & \\
\hline \multirow{4}{*}{$\begin{array}{l}\text { Codon } 3611 \text { Msp1 } \\
\text { (rs1801701) }\end{array}$} & 5'-AGAACATACAAGCAAAGCCA-3' & $94^{\circ} \mathrm{C} 5$ mins & \multirow[t]{4}{*}{273} & \multirow[t]{2}{*}{169} & \multirow[t]{4}{*}{ Pan et al. [31] } \\
\hline & \multirow[t]{3}{*}{ 5'-GAGGAACCTTAGGTGTCCTTC-3' } & $94^{\circ} \mathrm{C} 0.30 \mathrm{sec}, 56^{\circ} \mathrm{C} 30 \mathrm{sec}$ & & & \\
\hline & & $70^{\circ} \mathrm{C} 0.30 \mathrm{sec}(40$ cycles $)$ & & \multirow[t]{2}{*}{104} & \\
\hline & & $70^{\circ} \mathrm{C} 10$ mins, hold at $4^{\circ} \mathrm{C}$ & & & \\
\hline \multirow{4}{*}{$\begin{array}{l}\text { Codon } 4154 \text { EcoR1 } \\
\text { (rs1042031) }\end{array}$} & 5'-TAGGCAAATTGATGATATCGA-3' & $94^{\circ} \mathrm{C} 5$ mins & \multirow[t]{4}{*}{330} & \multirow[t]{2}{*}{181} & \multirow[t]{4}{*}{ Pan et al. [31] } \\
\hline & \multirow[t]{3}{*}{ 5'-ACCTGGGACAGTACCGTCCCTA-3' } & $94^{\circ} \mathrm{C} 0.30 \mathrm{sec}, 54^{\circ} \mathrm{C} 30$ & & & \\
\hline & & $\mathrm{sec}, 70^{\circ} \mathrm{C} 0.30 \mathrm{sec}(40$ cycles $)$ & & \multirow[t]{2}{*}{149} & \\
\hline & & $70^{\circ} \mathrm{C} 10$ mins, hold at $4^{\circ} \mathrm{C}$ & & & \\
\hline \multirow[t]{4}{*}{ 3'VNTR } & \multirow[t]{2}{*}{ 5'-6- FAM- ATGGAAACGGAGAAATTATG-3' } & $95^{\circ} \mathrm{C} 5$ mins & \multirow[t]{4}{*}{$500-900$} & \multirow[t]{4}{*}{ N/A } & \multirow[t]{4}{*}{ Alonso et al. [30] } \\
\hline & & $94^{\circ} \mathrm{C} 1 \mathrm{~min}, 58^{\circ} \mathrm{C} 1 \mathrm{~min}$ & & & \\
\hline & \multirow[t]{2}{*}{ 5'-CCTTCTCACTTGGCAAATAC-3' } & $72^{\circ} \mathrm{C} 4$ mins (29 cycles) & & & \\
\hline & & $72^{\circ} \mathrm{C} 7$ mins, hold at $4^{\circ} \mathrm{C}$ & & & \\
\hline
\end{tabular}

KC818417 (Xba1-Exon 26), KC818418 (Msp1-Exon 26) and KC818416 (Ecor1-Exon 29), respectively.

\section{Genotyping and allele designation of the $A P O B 3^{\prime} V N T R$ polymorphism}

Amplification of the variable tandem repeats at the $3^{\prime}$ end flanking the second polyadenylation signal was carried out by PCR based on the method described by Alonso et al. [30] followed by gene fragment analysis on the ABI Gene Analyzer 3130xl (Applied Biosystems, Life Technologies, Paisly, UK). Allele designation of the 3' VNTR locus at the $A P O B$ gene locus was established by determining the molecular size of the PCR products of the samples as compared with the ROX standard and positive controls. The positive controls were obtained by sequencing randomly selected samples $(n=10)$ to determine their exact size as base pairs and their corresponding alleles were designated according to Ludwig et al. [14]. To detect possible associations and simplify allele interaction analysis, the alleles were reassigned into a diallelic system where alleles $<39$ were coded as medium $(\mathrm{M})$ and those that were $\geq 39$ were coded as long (L).

\section{Analysis of genotype and allele frequency and} Hardy-Weinberg equilibrium

The allele and genotype frequencies were determined by simple counting of all five polymorphisms including the signal peptide (rs11279109), XbaI (rs693), MspI (rs1801701), EcoRI (rs1042031) in the total population $(\mathrm{n}=795)$ and with regards to plasma lipid levels and documented family history of various complex diseases (Table 1). The Hardy-Weinberg equilibrium (HWE) for the general population was estimated based on Chi-square using GENEPOP (Version 4.0.10) [42]. A $\mathrm{p}$-value $\leq 0.05$ indicated deviation from HWE.

\section{Haplotype construction and analysis}

Linkage disequilibrium between the RFLP marker alleles at the $A P O B$ gene loci and their mutations have been reported to possibly have an effect on the phenotype, and that this may differ from one population to another [27]. Such SNPs can be used to construct haplotypes. In the present study, the 5 SNPs studied were used to construct the common haplotypes among the Kuwaiti population and their frequencies were estimated using Haploview 9 (Version 4.1). A total of 32 different haplotypes were recorded. Since the gametic phase of the samples is unknown, each sample was labeled as a carrier of the given haplotype based on their allelic combination for the five SNPs. In addition, univariate (ANOVA) analysis was carried out to investigate the association of the major haplotypes $(>3 \%)$ observed with variation to lipid levels and other variables. 


\section{Statistical analysis}

Statistical analyses on the differences in the genotypic and allele frequency distribution were determined with regards to gender, BMI, and positive family history of hypercholesterolemia (HC), hypertriglyceridemia (HTG), hypertension (HT), diabetes mellitus (DM) and heart disease (HD) using the IBM SPSS Windows version 19.0. TG, TC, HDL-C, LDL-C values were natural logtransformed to achieve approximate normal distributions before further analysis. Chi-square tests were used to find the association between categorical variables including categorical lipid levels (lipid levels were divided into two main groups: normal levels and abnormal levels based on the cut-off value criteria of the American Heart Association for TC, TG, LDL-C and HDL-C). Moreover, genotype and allele frequency distribution for each SNP was compared with regards to the mean and standard deviation of plasma lipid levels using univariate ANOVA test. A two-tailed p-value of 0.05 was considered statistically significant. Bonferroni correction for multiple testing was taken into consideration but was not applied. In addition, logistic regression analyses were performed to investigate the association of the studied SNPs with lipid levels (Outcome variables: lipid levels, $0=$ desirable levels and $1=$ abnormal levels). Power calculations was estimated on a sample size of 100 from each ethnic group to detect the differences (delta) in the mean distribution of each polymorphism mean using the $G$ *Power 3 statistical power analysis program [43]. Moreover, the sample size of $n=665$ was analyzed using the Power and
Sample Calculation Program (version 3.0.43) to detect power for the association of the significant SNPs with variation in lipid levels.

\section{Results}

All 795 samples were successfully amplified and the expected PCR products of $93 \mathrm{bp}$ for the insertion allele and the $84 \mathrm{bp}$ for the deletion alleles were observed among all the samples (Additional file 1: Figure A). Table 3 summarizes the genotype and allele frequencies observed as well as the heterozygosity estimates for the signal peptide (rs11279109), XbaI (rs693), MspI (rs1801701) and EcoRI (rs1042031) polymorphisms.

Table 4 summarizes the results of logistic regression analysis with regards to TG levels only. The other lipid levels did not show any significance (Additional file 2: Tables A-C). The genotype and allele frequencies distribution for the major variables analyzed including variation to lipid levels and positive family history of dyslipidemia are summarized in Table 5. The results for all the variables analyzed with regards to all five $A P O B$ polymorphisms including univariate analysis are summarized in the Additional file 3: Tables A-E.

\section{Genotyping the signal peptide polymorphism at the $A P O B$ gene locus and its association to variation in lipid levels}

The most common genotype observed (Table 3 ) was that for the homozygote insertion allele $(n=483,60.75 \%)$ followed by the heterozygote allele $(n=265,33.33 \%)$.

Table 3 Genotype and allele frequencies of the five $A P O B$ polymorphisms analyzed $(n=795)$

\begin{tabular}{|c|c|c|c|c|c|c|c|}
\hline \multirow{2}{*}{$\frac{\text { Polymorphism }}{\text { SP (rs11279109) }}$} & \multicolumn{3}{|c|}{ Genotype } & \multicolumn{2}{|c|}{ Allele } & \multirow[t]{2}{*}{ HWE } & \multirow[t]{2}{*}{ Heterozygosity estimate } \\
\hline & II & ID & $\mathrm{DD}$ & 1 & D & & \\
\hline$n$ & 483 & 265 & 47 & \multirow{2}{*}{0.77} & \multirow{2}{*}{0.23} & \multirow[t]{2}{*}{$p=0.638$} & \multirow[t]{2}{*}{0.33} \\
\hline$(\%) / f$ & 60.75 & 33.33 & 5.91 & & & & \\
\hline VNTR & MM & ML & LL & $M$ & $\mathbf{L}$ & \multirow{3}{*}{$p=0.013$} & \multirow{3}{*}{0.15} \\
\hline$n$ & 655 & 116 & 24 & \multirow{2}{*}{0.90} & \multirow{2}{*}{0.10} & & \\
\hline$(\%) / f$ & 82.39 & 14.59 & 3.02 & & & & \\
\hline Xba1 (rs693) & $x^{-} x^{-}$ & $\mathrm{X}^{+} \mathrm{X}^{-}$ & $\mathrm{X}^{+} \mathrm{X}^{+}$ & $x^{-}$ & $\mathrm{X}^{+}$ & \multirow{3}{*}{$p=0.717$} & \multirow{3}{*}{0.39} \\
\hline$n$ & 430 & 308 & 57 & \multirow{2}{*}{0.73} & \multirow{2}{*}{0.27} & & \\
\hline$(\%) / f$ & 54.09 & 38.74 & 7.17 & & & & \\
\hline Msp1 (rs1801701) & $M^{+} M^{+}$ & $M^{+} M^{-}$ & $M^{-} M^{-}$ & $\mathrm{M}^{+}$ & $M^{-}$ & \multirow{3}{*}{$p=0.599$} & \multirow{3}{*}{0.12} \\
\hline$n$ & 692 & 99 & 4 & \multirow{2}{*}{0.93} & \multirow{2}{*}{0.07} & & \\
\hline$(\%) / f$ & 87.04 & 12.45 & 0.50 & & & & \\
\hline EcoR1 (rs1042031) & $E^{+} E^{+}$ & $E^{+} E^{-}$ & $E^{-} E^{-}$ & $\mathrm{E}^{+}$ & $\mathrm{E}^{-}$ & \multirow{3}{*}{$p=0.211$} & \multirow{3}{*}{0.18} \\
\hline$n$ & 640 & 142 & 13 & \multirow{2}{*}{0.89} & \multirow{2}{*}{0.11} & & \\
\hline$(\%) / f$ & 80.50 & 17.86 & 1.64 & & & & \\
\hline
\end{tabular}

The table summarizes the genotypes for the signal peptide (SP) (rs11279109), variable number of tandem repeats (3'VNTR), Codons $2488-\mathrm{Xbal} C\left(\mathrm{X}^{-}\right)<\mathrm{T}\left(\mathrm{X}^{+}\right)$ (rs693), 3611-Mspl $G\left(M^{-}\right)<A\left(M^{+}\right)$(rs1801701) and 4154-EcoRI $G\left(E^{-}\right)<A\left(E^{+}\right)$(rs1042031).

$\mathrm{n}$ : number of samples, f: allele frequency HWE: Hardy-Weinberg Equilibrium with significant $\mathrm{p}$ - value level at 0.05 . 
Table 4 Results of logistic regression analysis of the $A P O B$ polymorphisms and TG levels (Outcome variable TG; $0=\leq 1.7 \mathrm{mmol} / \mathrm{L}$ and $1=>1.7 \mathrm{mmol} / \mathrm{L}$ )

\begin{tabular}{|c|c|c|c|c|c|c|}
\hline & Odds ratio (crude) & $95 \% \mathrm{Cl}^{\mathrm{a}}$ & $p$-value & Odds ratio (adjusted) ${ }^{b}$ & $95 \% \mathrm{Cl}^{\mathrm{a}}$ & p-value \\
\hline \multicolumn{7}{|c|}{ SP (rs11279109) } \\
\hline$\|$ & 1.00 & & & 1.00 & & \\
\hline ID & 0.49 & $0.29-0.82$ & 0.007 & 0.53 & $0.31-0.92$ & 0.023 \\
\hline DD & 1.04 & $0.44-2.45$ & 0.931 & 1.01 & $0.41-2.48$ & 0.990 \\
\hline \multicolumn{7}{|c|}{ Xba1 (rs693) } \\
\hline$x^{-} X^{-}$ & 1.00 & & & 1.00 & & \\
\hline$X^{+} X^{-}$ & 0.93 & $0.59-1.46$ & 0.753 & 0.98 & $0.60-1.57$ & 0.917 \\
\hline$X^{+} X^{+}$ & 0.76 & $0.31-1.88$ & 0.558 & 0.82 & $0.32-2.11$ & 0.680 \\
\hline \multicolumn{7}{|c|}{ Msp1 (rs1801701) } \\
\hline $\mathrm{M}^{+} \mathrm{M}^{+}$ & 1.00 & & & 1.00 & & \\
\hline $\mathrm{M}^{+} \mathrm{M}^{-}$ & 0.62 & $0.29-1.33$ & 0.220 & 0.72 & $0.32-1.61$ & 0.424 \\
\hline $\mathrm{M}^{-} \mathrm{M}^{-}$ & 5.81 & $0.81-41.82$ & 0.080 & 8.80 & $1.13-68.46$ & 0.038 \\
\hline \multicolumn{7}{|c|}{ EcoR1 (rs1042031) } \\
\hline$E^{+} E^{+}$ & 1.00 & & & 1.00 & & \\
\hline$E^{+} E^{-}$ & 0.95 & $0.53-1.70$ & 0.867 & 0.93 & $0.50-1.71$ & 0.810 \\
\hline$E^{-} E^{-}$ & 2.28 & $0.59-8.77$ & 0.232 & 2.47 & $0.56-10.81$ & 0.231 \\
\hline \multicolumn{7}{|l|}{ VNTR } \\
\hline MM & 1.00 & & & 1.00 & & \\
\hline $\mathrm{ML}$ & 0.65 & $0.32-1.29$ & 0.217 & 0.66 & $0.32-1.37$ & 0.264 \\
\hline LL & 1.00 & $0.29-3.50$ & 0.996 & 0.90 & $0.23-3.49$ & 0.875 \\
\hline
\end{tabular}

The table summarizes the results for the signal peptide (SP) (rs11279109), variable number of tandem repeats ( $\left.3^{\prime} \mathrm{VNTR}\right)$, Codons $2488-\mathrm{Xbal} C\left(\mathrm{X}^{-}\right)<\mathrm{T}\left(\mathrm{X}^{+}\right)(\mathrm{rs} 693)$, 3611-Mspl $\mathrm{G}\left(\mathrm{M}^{-}\right)<\mathrm{A}\left(\mathrm{M}^{+}\right)$(rs1801701) and 4154-EcoRI $\mathrm{G}\left(\mathrm{E}^{-}\right)<\mathrm{A}\left(\mathrm{E}^{+}\right)$(rs1042031).

${ }^{a} 95 \% \mathrm{Cl}=95 \%$ confidence interval for odds ratio with significant $\mathrm{p}$ - value level at 0.05 .

${ }^{\mathrm{b}}$ Adjusted for gender and age.

Both the genotype and allele frequencies $(\mathrm{I}=0.77, \mathrm{D}=$ $0.23)$ were found to be in HWE $(\mathrm{p}>0.05)$ with a mean heterozygosity value of 0.33 .

The analysis (Table 5) showed a significant association between the insertion allele $(\mathrm{p}=0.04)$ and increased levels of TG $(>1.70 \mathrm{mmol} / \mathrm{L}, \mathrm{n}=95)$. There was a significantly $(\mathrm{p}=0.021)$ lower frequency $(22.1 \%)$ of heterozygotes with increased TG levels than heterozygotes with normal TG levels (36.8\%). Regression analysis further confirmed the association by showing a half-fold risk for heterozygotes (Table 4). These results were further supported by the univariate analysis of the mean values of the lipid levels which also revealed a significant association between heterozygotes and variation in TG level (Additional file 3: Table A). The analysis showed that heterozygotes had significantly $(\mathrm{p}=0.044)$ lower mean TG levels $(0.95 \pm 0.0)$ than homozygotes for either the deletion or the insertion allele. Moreover, a significant association was observed $(\mathrm{p}=0.004)$ with regards to family history of HTG but the sample size of those with positive family history is too small to allow definite conclusions.
Genotyping the SNPS (codons 2488, 3611 and 4154) at the $A P O B$ Exon 26 and 29 and its association with variation in lipid levels

All 795 samples were successfully amplified and the expected PCR products for each of the three polymorphisms (2488, 3611 and 4154) were observed (Additional file 1: Figure B-D). The expected genotypes were observed (Table 3) with the highest frequency being that for the homozygous wild type allele for all three SNPs with no significant differences or deviation from HWE $(\mathrm{p}>0.05)$ among all the samples analyzed $(n=795)$. The highest mean heterozygosity estimate (0.39) was observed for the $A P O B$ codon $2488 \mathrm{Xbal}$ SNP. The rare allele absent of the MspI restriction site for the $A P O B$ codon 3611 was found to be less than $1 \%$ (Table 3) contributing to the low mean heterozygosity estimate of 0.12. Similarly, the rare allele (absence of the restriction site) for the $A P O B$ EcoRI was found to be approximately $1.1 \%$ in the studied population also contributing to the low mean heterozygosity estimate $(0.18)$.

No significant differences were observed with regards to variation in lipid levels and the other variables 
Table 5 Distribution of genotype and allele frequencies of the $A P O B$ polymorphisms with the major variables analyzed among the Kuwaiti population $(n=795)$

\begin{tabular}{|c|c|c|c|c|c|c|c|c|c|c|c|c|}
\hline & \multicolumn{2}{|c|}{ TC } & \multicolumn{2}{|c|}{ TG } & \multicolumn{2}{|c|}{ HDL-C } & \multicolumn{2}{|c|}{ LDL-C } & \multicolumn{2}{|c|}{$\mathrm{FH}-\mathrm{HC}$} & \multicolumn{2}{|c|}{ FH-HTG } \\
\hline & $\begin{array}{l}\text { Normal } \\
(5.17)\end{array}$ & $\begin{array}{l}\text { High } \\
(>5.17)\end{array}$ & $\begin{array}{l}\text { Normal } \\
(\leq 1.70)\end{array}$ & $\begin{array}{l}\text { High } \\
(>1.70)\end{array}$ & $\begin{array}{l}\text { Normal (>1.1 } \\
\text { men \& }>1.29 \\
\text { women) }\end{array}$ & $\begin{array}{l}\text { Abnormal }(\leq 1.1 \\
\text { men } \& \leq 1.29 \\
\text { women) }\end{array}$ & $\begin{array}{l}\text { Normal } \\
(\leq 3.2)\end{array}$ & $\begin{array}{l}\text { High } \\
(>3.2)\end{array}$ & Absent & Present & Absent & Present \\
\hline$n$ & 475 & 191 & 571 & 95 & 211 & 418 & 389 & 238 & 409 & 197 & 594 & 12 \\
\hline \multicolumn{13}{|l|}{$\begin{array}{l}A P O B \text { signal } \\
\text { peptide } \\
\text { (rs11279109) }\end{array}$} \\
\hline II n (\%) & $\begin{array}{c}277 \\
(58.3)\end{array}$ & $\begin{array}{l}118 \\
(61.8)\end{array}$ & $\begin{array}{c}338 \\
(57.4)\end{array}$ & $\begin{array}{l}67 \\
(70.5)\end{array}$ & $118(55.9)$ & $258(61.7)$ & $\begin{array}{c}233 \\
(59.9)\end{array}$ & $\begin{array}{c}141 \\
(59.2)\end{array}$ & $\begin{array}{c}248 \\
(60.64)\end{array}$ & $\begin{array}{c}121 \\
(61.42)\end{array}$ & $\begin{array}{c}364 \\
(61.28)\end{array}$ & $\begin{array}{c}5 \\
(41.67)\end{array}$ \\
\hline ID n (\%) & $\begin{array}{c}172 \\
(36.2)\end{array}$ & $\begin{array}{c}59 \\
(30.9)\end{array}$ & $\begin{array}{c}210 \\
(36.8)\end{array}$ & $\begin{array}{c}21 \\
(22.1)\end{array}$ & $81(38.4)$ & $135(32.3)$ & $\begin{array}{c}134 \\
(34.5)\end{array}$ & $\begin{array}{c}82 \\
(34.5)\end{array}$ & $\begin{array}{c}138 \\
(33.7)\end{array}$ & $\begin{array}{c}63 \\
(32.0)\end{array}$ & $\begin{array}{c}198 \\
(33.3)\end{array}$ & $3(25.0)$ \\
\hline DD n (\%) & $26(5.5)$ & $14(7.3)$ & $33(5.8)$ & $7(7.4)$ & $12(5.7)$ & $25(6.0)$ & $22(5.7)$ & $\begin{array}{l}15 \\
(6.3)\end{array}$ & $23(5.6)$ & $13(6.6)$ & $32(5.4)$ & $4(33.3)$ \\
\hline$p$ & 0.338 & & 0.021 & & 0.313 & & 0.944 & & 0.839 & & 0.004 & \\
\hline$D(f)$ & 0.236 & 0.228 & 0.242 & 0.184 & 0.249 & 0.221 & 0.229 & 0.235 & 0.225 & 0.226 & 0.221 & 0.458 \\
\hline I (f) & 0.764 & 0.772 & 0.758 & 0.816 & 0.751 & 0.779 & 0.771 & 0.765 & 0.775 & 0.774 & 0.779 & 0.542 \\
\hline$p$ & 0.754 & & 0.083 & & 0.274 & & 0.791 & & 0.970 & & 0.006 & \\
\hline \multicolumn{13}{|l|}{$\begin{array}{l}\text { APOB Codon } \\
2488 C \text { (rs693) }\end{array}$} \\
\hline$X^{-} X^{-} n(\%)$ & $\begin{array}{c}239 \\
(50.3)\end{array}$ & $\begin{array}{c}104 \\
(54.5)\end{array}$ & $\begin{array}{l}292 \\
(51.1)\end{array}$ & $\begin{array}{c}51 \\
(53.7)\end{array}$ & $111(52.6)$ & $217(52.6)$ & $\begin{array}{c}206 \\
(53.0)\end{array}$ & $\begin{array}{c}122 \\
(51.3)\end{array}$ & $\begin{array}{c}226 \\
(55.3)\end{array}$ & $\begin{array}{l}106 \\
(53.8)\end{array}$ & $\begin{array}{c}326 \\
(54.9)\end{array}$ & $6(50.0)$ \\
\hline X + X- n (\%) & $\begin{array}{c}199 \\
(41.9)\end{array}$ & $\begin{array}{c}73 \\
(38.2)\end{array}$ & $\begin{array}{c}234 \\
(41.0)\end{array}$ & $\begin{array}{c}38 \\
(40.0)\end{array}$ & 84 (39.8) & $168(40.2)$ & $\begin{array}{c}152 \\
(39.1)\end{array}$ & $\begin{array}{c}98 \\
(41.2)\end{array}$ & $\begin{array}{c}153 \\
(37.4)\end{array}$ & $\begin{array}{c}79 \\
(40.1)\end{array}$ & $\begin{array}{c}229 \\
(38.6)\end{array}$ & $3(25.0)$ \\
\hline $\mathrm{X}^{+} \mathrm{X}^{+} \mathrm{n}(\%)$ & $37(7.8)$ & $14(7.3)$ & $45(7.9)$ & $6(6.3)$ & $16(7.6)$ & $33(7.9)$ & $31(8.0)$ & $\begin{array}{l}18 \\
(7.6)\end{array}$ & $30(7.3)$ & $12(6.1)$ & $39(6.6)$ & $3(25.0)$ \\
\hline$p$ & 0.625 & & 0.826 & & 0.982 & & 0.871 & & 0.741 & & 0.041 & \\
\hline$X^{-}(f)$ & 0.713 & 0.736 & 0.716 & 0.737 & 0.725 & 0.720 & 0.725 & 0.718 & 0.740 & 0.739 & 0.742 & 0.625 \\
\hline$X^{+}(f)$ & 0.287 & 0.264 & 0.284 & 0.263 & 0.275 & 0.280 & 0.275 & 0.282 & 0.260 & 0.261 & 0.258 & 0.375 \\
\hline$p$ & 0.399 & & 0.559 & & 0.851 & & 0.805 & & 0.969 & & 0.198 & \\
\hline \multicolumn{13}{|l|}{$\begin{array}{l}\text { APOB Codon } \\
3611-M s p l \text { G } \\
\text { (rs1801701) }\end{array}$} \\
\hline$M^{+} M^{+} n(\%)$ & $\begin{array}{l}407 \\
(85.7)\end{array}$ & $\begin{array}{c}172 \\
(90.1)\end{array}$ & $\begin{array}{c}494 \\
(86.5)\end{array}$ & $\begin{array}{c}85 \\
(89.5)\end{array}$ & $180(85.3)$ & $368(88.0)$ & $\begin{array}{c}337 \\
(86.6)\end{array}$ & $\begin{array}{l}209 \\
(87.8)\end{array}$ & $\begin{array}{c}362 \\
(88.5)\end{array}$ & $\begin{array}{c}162 \\
(82.2)\end{array}$ & $\begin{array}{c}516 \\
(86.9)\end{array}$ & $8(66.7)$ \\
\hline$M^{+} M^{-} n(\%)$ & $65(13.7)$ & $18(9.4)$ & $75(13.1)$ & $8(8.4)$ & $30(14.2)$ & $47(11.2)$ & $49(12.6)$ & $\begin{array}{c}28 \\
(11.8)\end{array}$ & $\begin{array}{c}45 \\
(11.0)\end{array}$ & $35(17.8)$ & $\begin{array}{c}76 \\
(12.8)\end{array}$ & $4(33.3)$ \\
\hline$M^{-} M^{-} n(\%)$ & $3(0.6)$ & $1(0.5)$ & $2(0.4)$ & $2(2.1)$ & $1(0.5)$ & $3(0.7)$ & $3(0.8)$ & $1(0.4)$ & $2(0.5)$ & $0(0.0)$ & $2(0.3)$ & $0(0.0)$ \\
\hline$p$ & 0.315 & & 0.058 & & 0.532 & & 0.822 & & 0.046 & & 0.113 & \\
\hline$M^{-}(f)$ & 0.075 & 0.052 & 0.069 & 0.063 & 0.076 & 0.063 & 0.071 & 0.063 & 0.060 & 0.089 & 0.067 & 0.167 \\
\hline$M^{+}(f)$ & 0.925 & 0.948 & 0.931 & 0.937 & 0.924 & 0.937 & 0.929 & 0.937 & 0.940 & 0.911 & 0.933 & 0.833 \\
\hline$p$ & 0.143 & & 0.761 & & 0.407 & & 0.600 & & 0.063 & & 0.079 & \\
\hline \multicolumn{13}{|l|}{$\begin{array}{l}A P O B \text { Codon } \\
4154 G \\
\text { (rs1042031) }\end{array}$} \\
\hline$E^{+} E^{+} n(\%)$ & $\begin{array}{c}383 \\
(80.6)\end{array}$ & $\begin{array}{c}154 \\
(80.6)\end{array}$ & $\begin{array}{c}461 \\
(80.7)\end{array}$ & $\begin{array}{c}76 \\
(80.0)\end{array}$ & $174(82.5)$ & $334(79.9)$ & $\begin{array}{c}319 \\
(82.0)\end{array}$ & $\begin{array}{l}187 \\
(78.6)\end{array}$ & $\begin{array}{c}321 \\
(78.5)\end{array}$ & $\begin{array}{c}158 \\
(80.2)\end{array}$ & $\begin{array}{c}468 \\
(78.8)\end{array}$ & $11(91.7)$ \\
\hline$E^{+} E^{-} n(\%)$ & $83(17.5)$ & $\begin{array}{c}35 \\
(18.3)\end{array}$ & $\begin{array}{c}102 \\
(17.9)\end{array}$ & $\begin{array}{c}16 \\
(16.8)\end{array}$ & $34(16.1)$ & $77(18.4)$ & $63(16.2)$ & $\begin{array}{c}48 \\
(20.2)\end{array}$ & $\begin{array}{c}82 \\
(20.0)\end{array}$ & $33(16.8)$ & $\begin{array}{c}114 \\
(19.2)\end{array}$ & $1(8.3)$ \\
\hline$E^{-} E^{-} n(\%)$ & $8(1.9)$ & $2(1.1)$ & $8(1.4)$ & $3(3.2)$ & $3(1.4)$ & $7(1.7)$ & $7(1.8)$ & $3(1.3)$ & $6(1.5)$ & $6(3.0)$ & $12(2.0)$ & $0(0.0)$ \\
\hline
\end{tabular}


Table 5 Distribution of genotype and allele frequencies of the $A P O B$ polymorphisms with the major variables analyzed among the Kuwaiti population $(\mathbf{n}=\mathbf{7 9 5})$ (Continued)

\begin{tabular}{|c|c|c|c|c|c|c|c|c|c|c|c|c|}
\hline$p$ & 0.723 & & 0.455 & & 0.743 & & 0.406 & & 0.289 & & 0.543 & \\
\hline$E^{-}(f)$ & 0.106 & 0.102 & 0.103 & 0.116 & 0.095 & 0.109 & 0.099 & 0.113 & 0.115 & 0.114 & 0.116 & 0.042 \\
\hline$E^{+}(f)$ & 0.894 & 0.898 & 0.897 & 0.884 & 0.905 & 0.891 & 0.901 & 0.887 & 0.885 & 0.886 & 0.884 & 0.958 \\
\hline$p$ & 0.820 & & 0.604 & & 0.441 & & 0.416 & & 0.971 & & 0.257 & \\
\hline \multicolumn{13}{|c|}{$A P O B 3$ VNTR } \\
\hline MM n (\%) & $\begin{array}{c}391 \\
(82.3)\end{array}$ & $\begin{array}{c}157 \\
(82.2)\end{array}$ & $\begin{array}{c}466 \\
(81.6)\end{array}$ & $\begin{array}{c}82 \\
(86.3)\end{array}$ & $174(82.5)$ & $345(82.5)$ & $\begin{array}{c}321 \\
(82.5)\end{array}$ & $\begin{array}{c}197 \\
(82.8)\end{array}$ & $\begin{array}{c}339 \\
(82.9)\end{array}$ & $\begin{array}{c}168 \\
(85.3)\end{array}$ & $\begin{array}{c}496 \\
(83.5)\end{array}$ & $11(91.7)$ \\
\hline ML n (\%) & $68(14.3)$ & $\begin{array}{c}30 \\
(15.7)\end{array}$ & $88(15.4)$ & $\begin{array}{c}10 \\
(10.5)\end{array}$ & $30(14.2)$ & $62(14.8)$ & $56(14.4)$ & $\begin{array}{c}35 \\
(14.7)\end{array}$ & $\begin{array}{c}56 \\
(13.7)\end{array}$ & $22(11.2)$ & $\begin{array}{c}77 \\
(13.0)\end{array}$ & $1(8.3)$ \\
\hline LL n (\%) & $16(3.4)$ & $4(2.1)$ & $17(3.0)$ & $3(3.2)$ & $7(3.3)$ & $11(2.6)$ & $12(3.1)$ & $6(2.5)$ & $14(3.4)$ & 7(3.6 & $21(3.5)$ & $\mathrm{O}(0.0)$ \\
\hline $\mathrm{p}$ & 0.633 & & 0.461 & & 0.875 & & 0.916 & & 0.685 & & 0.700 & \\
\hline$L(f)$ & 0.105 & 0.099 & 0.107 & 0.084 & 0.104 & 0.100 & 0.103 & 0.099 & 0.103 & 0.091 & 0.100 & 0.042 \\
\hline$M(f)$ & 0.895 & 0.901 & 0.893 & 0.916 & 0.896 & 0.900 & 0.897 & 0.901 & 0.897 & 0.909 & 0.900 & 0.958 \\
\hline $\mathrm{p}$ & 0.754 & & 0.343 & & 0.834 & & 0.816 & & 0.537 & & 0.503 & \\
\hline
\end{tabular}

TC total cholesterol (expressed in mmol/L); TG triglycerides (expressed in $\mathrm{mmol} / \mathrm{L}$ ); LDL-C low density lipoprotein-cholesterol; HDL-C high density lipoprotein-cholesterol; FH-HTG positive family history of hypertriglyceridemia, FH-HC positive family history of hypercholesterolemia.

$\mathrm{n}=$ number of samples, $\%=$ frequency for each genotype in percent and ratio (f) for the allele.

The $p$-values were determined by chi-square test at a significance level of $p=0.05$.

analyzed (Additional file 3: Table B) with the $A P O B$ XbaI polymorphism. The distribution of the genotype and allele frequencies was found to be similar among the different groups analyzed for the major variables (Table 5).

Analysis of the genotype and allele distribution for the $A P O B 3611$ MspI polymorphism for the major variables analyzed (Table 5) revealed a probable significant association $(\mathrm{p}=0.058)$ with serum TG levels. The rare allele $\mathrm{M}^{-}$was observed to be higher in individuals with normal TG levels $(\mathrm{n}=571)$ as indicated by the higher frequency $(13.10 \%)$ of heterozygous samples carrying the rare $\mathrm{M}^{-}$allele as compared to the $8.4 \%$ of individuals with increased levels of TG level $(n=95)$ and whom were mostly homozygotes $(n=85,89.5 \%)$ for the wild type $\mathrm{M}^{+}$allele implicating the $\mathrm{M}^{-}$as a "protective allele". Univariate analysis of the mean and standard deviation of the lipid levels revealed a possible significant association of heterozygous $\mathrm{M}^{+} \mathrm{M}^{-}$with TG levels and BMI (Additional file 3: Table $\mathrm{C}$ ). The analysis showed that heterozygotes showed a trend $(\mathrm{p}=0.07)$ for lower mean TG levels $(0.88 \pm 0.9)$ than homozygous for either allele. Logistic regression analysis (Table 4) also showed a significant $(\mathrm{p}=0.038) 8.8$ fold increased probability of having lower TG levels $(<1.70 \mathrm{mmol} / \mathrm{L})$ in individuals with the homozygous $\mathrm{M}^{-} \mathrm{M}^{-}$genotype. Moreover, individuals with positive family history of hypercholesterolemia $(n=197)$ had a significantly different genotype distribution $(p=0.046)$ where there were more heterozygous samples present (17.8\%) than those without a positive family history of hypercholesterolemia $(n=409)$ (Table 5).
The analysis of the genotype and allele distribution for the $A P O B$ 4154 EcoRI polymorphism (Table 5) did not reveal any significant correlation with any of the lipid levels. Univariate analysis also did not show any significance with regards to the genotype distribution against the mean and standard deviation of serum lipid levels and BMI (Additional file 3: Table D).

\section{Genotyping and allele designation of the $A P O B 3^{\prime}$ VNTR polymorphism and its association to variation in lipid levels}

Gene fragment analysis of the 3' VNTR locus (Figure 1) was found to be a simple and a rapid method for highthroughput genotyping. The data obtained proved to be highly variable in the Kuwaiti population with at least 43 different genotypes observed comprising 11 alleles ranging from as little as 31 repeats to as high as 51. In the derived diallelic classification, the most common genotype observed was that for the homozygous medium allele $(\mathrm{n}=655,82.39 \%)$ followed by the heterozygous $(\mathrm{n}=116,14.59 \%)$ and the least common was for the homozygous long allele $(\mathrm{n}=24,3.02 \%)$. The genotype frequencies for the derived classification of the $\mathrm{M}$ and $\mathrm{L}$ allele were found to deviate from the HWE $(p=0.013)$ contributing to the observed low mean heterozygosity value of 0.15 (Table 3 ). The deviation may also be the outcome of the cut-off values used in assigning the $\mathrm{M}$ and $\mathrm{L}$ alleles.

The genotype and allele frequencies were also compared among the different groups (Table 5) and with 


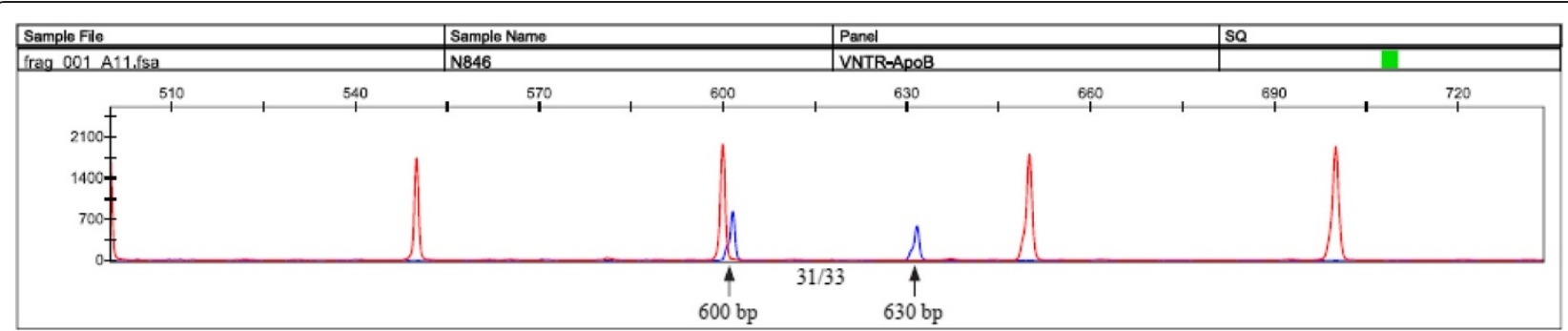

Figure 1 An electropherogram of the $A P O B 3^{\prime}$ VNTR polymorphism for a heterozygote sample generated by PCR and gene fragment analysis. The peaks represent the alleles detected which are determined by comparison to a ROX standard. The sample shown was genotyped as 31/33 based on the number of repeats determined by their corresponding molecular size of $600 \mathrm{bp}$ and 630 bp indicated with and an arrow on the figure. In the derived classification, this Kuwaiti sample was genotyped as M/L.

all the variables analyzed (Additional file 3: Table E). No significant findings were observed with regards to variation in lipid levels.

\section{Haplotype Analysis of the $A P O B$ gene polymorphisms and} their associations to variations in lipid levels

All five polymorphisms were found to be in linkage disequilibrium ( $\mathrm{p} \leq 0.05)$ and hence were used to construct haplotypes. A total of 32 different haplotypes were observed among all the samples $(n=795)$. The haplotypes and their frequencies are summarized in Table 6. Haplotypes with less than a $3 \%$ frequency were grouped as other "O" haplotypes making up $24.1 \%$ of the total observed haplotypes. The most common observed haplotype "A" (28.9\%) was that which consisted of all the wild type alleles at the five $A P O B$ loci while only one sample $(0.04 \%)$ was observed with all rare alleles at the five loci. The haplotypes were examined for carrier status in all the samples and then were analyzed for their association with variation in lipid levels (Table 7). Carriers of

Table 6 Haplotypes at the $A P O B$ gene locus and their frequencies as observed in the population sample analyzed

\begin{tabular}{|c|c|c|c|}
\hline Haplotype & Alleles* & $\mathrm{N}$ & Frequency (\%) \\
\hline$A$ & $\mathrm{IX}^{-} \mathrm{M}^{+} \mathrm{R}^{+} \mathrm{M}$ & 681 & 28.9 \\
\hline B & $I X^{+} M^{+} R^{+} M$ & 324 & 13.3 \\
\hline C & $\mathrm{DX}^{-} \mathrm{M}^{+} \mathrm{R}^{+} \mathrm{M}$ & 262 & 11.1 \\
\hline D & $D X^{+} M^{+} R^{+} M$ & 191 & 8.1 \\
\hline$E$ & $\mathrm{IX}^{-} \mathrm{M}^{+} \mathrm{R}-\mathrm{M}$ & 137 & 5.8 \\
\hline $\mathrm{F}$ & $\mathrm{IX}^{-} \mathrm{M}^{+} \mathrm{R}^{+} \mathrm{L}$ & 120 & 5.1 \\
\hline G & $I X^{-} M^{-} R^{+} M$ & 73 & 3.1 \\
\hline $\mathrm{O}$ & - & 568 & 24.1 \\
\hline
\end{tabular}

The carrier status is defined as a sample which has all five alleles associated with the given haplotype and their frequency (\%) is given. A sample may have more than one haplotype since the gametic phase is unknown. Haplotype " $O$ " includes grouped haplotypes observed that were less than $3 \%$.

*The alleles are for the polymorphisms in this order: rs11279109, rs693, rs1801701, rs1042031 and the 3'VNTR locus.

$\mathrm{N}=$ count number of carrier for each coded haplotype, $\%=$ frequency for each haplotype. haplotypes $\mathrm{G}\left(\mathrm{IX}^{-} \mathrm{M}^{-} \mathrm{E}^{+} \mathrm{M}\right)$ had a significantly $(\mathrm{p}=0.048)$ lower mean TG levels $(0.86 \pm 0.07)$ as compared to noncarriers whose mean TG levels were $1.01 \pm 0.02$.

\section{Discussion}

This study provides a comprehensive analysis of five $A P O B$ polymorphisms and their correlation with variations of serum lipid levels in the Kuwaiti population. Significant findings were observed for the genetic association between the $A P O B$ signal peptide (rs11279109) and MspI (rs1801701) polymorphisms with variation in TG levels among the Kuwaiti samples analyzed. Heterozygous samples at the $A P O B$ signal peptide locus were significantly $(\mathrm{p}=0.023)$ associated with lower TG serum levels (Tables 4 and 5). This may suggest an interaction between the two alleles to influence serum TG levels and thus genetically predispose individuals to dyslipidemia. This may also explain why several studies investigating the role of this SNP with variation in lipid levels and other disorders reported conflicting results. The two alleles were found at frequencies of more than $5 \%$ with an average heterozygosity estimate (0.33) revealing that both alleles could possibly exhibit different influences on serum lipid levels in different ethnic groups. Furthermore, univariate analysis of the $A P O B$ signal peptide polymorphism also revealed a significant $(\mathrm{p}=0.021)$ association between carriers of the insertion allele with lower mean serum TG. These abnormalities in lipid profile associated with the $A P O B$ signal peptide polymorphism may be the result of a change in the degree of hydrophobicity and efficacy of apoB processing $[16,41,44]$ due to either the presence or absence of the hydrophobic amino acid residues $[16,41,44]$. This is also reflected in the results obtained from the logistic regression (Table 4) analysis (both adjusted and unadjusted) which showed a half fold decrease in the risk of having increased TG levels for carriers of the insertion allele.

The SNP at $A P O B$ codon 3611 involves the loss of the ancestral restriction sites of MspI [13] as a result of a transition mutation changing a $\mathrm{G}$ to an $\mathrm{A}$ at codon 3611 in exon 26. In this study, most of the individuals 
Table 7 Association of the major haplotypes analyzed at the APOB gene locus and their association with variation in mean serum lipid levels (expressed in $\mathrm{mmol} / \mathrm{L}$ ) among the Kuwaiti samples analyzed

\begin{tabular}{llcccccccc}
\hline Lipid & Haplotype & $\mathbf{A}$ & $\mathbf{B}$ & $\mathbf{C}$ & $\mathbf{D}$ & $\mathbf{E}$ & $\mathbf{F}$ & $\mathbf{G}$ & $\mathbf{0}$ \\
\hline $\mathrm{N}$ & Non-carrier & 1675 & 2032 & 2094 & 2165 & 2219 & 2236 & 2283 & 1788 \\
& Carrier & 681 & 324 & 262 & 191 & 137 & 120 & 73 & 568 \\
$\mathrm{TC}$ & Non-carrier & $4.67 \pm 0.02$ & $4.69 \pm 0.02$ & $4.69 \pm 0.02$ & $4.69 \pm 0.02$ & $4.69 \pm 0.02$ & $4.69 \pm 0.02$ & $4.69 \pm 0.02$ & $4.70 \pm 0.02$ \\
& Carrier & $4.72 \pm 0.04$ & $4.71 \pm 0.05$ & $4.70 \pm 0.06$ & $4.69 \pm 0.07$ & $4.73 \pm 0.09$ & $4.61 \pm 0.10$ & $4.68 \pm 0.11$ & $4.65 \pm 0.04$ \\
& p value* & $\mathbf{0 . 3 5 6}$ & $\mathbf{0 . 7 6 7}$ & $\mathbf{0 . 8 7 9}$ & $\mathbf{0 . 9 3 7}$ & $\mathbf{0 . 6 6 7}$ & $\mathbf{0 . 4 1 7}$ & $\mathbf{0 . 9 3 5}$ & $\mathbf{0 . 2 9 8}$ \\
$\mathrm{TG}$ & Non-carrier & $1.00 \pm 0.02$ & $1.07 \pm 0.03$ & $1.01 \pm 0.02$ & $1.01 \pm 0.02$ & $1.01 \pm 0.02$ & $1.01 \pm 0.02$ & $1.01 \pm 0.02$ & $1.03 \pm 0.02$ \\
& Carrier & $1.05 \pm 0.05$ & $1.05 \pm 0.03$ & $1.00 \pm 0.05$ & $0.97 \pm 0.05$ & $1.05 \pm 0.08$ & $1.02 \pm 0.09$ & $0.86 \pm 0.07$ & $0.95 \pm 0.03$ \\
& p value* & $\mathbf{0 . 3 3 4}$ & $\mathbf{0 . 7 2 8}$ & $\mathbf{0 . 9 1 4}$ & $\mathbf{0 . 9 9 8}$ & $\mathbf{0 . 4 4 0}$ & $\mathbf{0 . 7 0 7}$ & $\mathbf{0 . 0 4 8}$ & $\mathbf{0 . 0 8 9}$ \\
HDL-C & Non-carrier & $1.14 \pm 0.01$ & $1.12 \pm 0.01$ & $1.13 \pm 0.01$ & $1.13 \pm 0.01$ & $1.14 \pm 0.01$ & $1.14 \pm 0.01$ & $1.13 \pm 0.01$ & $1.14 \pm 0.01$ \\
& Carrier & $1.14 \pm 0.02$ & $1.14 \pm 0.01$ & $1.16 \pm 0.02$ & $1.16 \pm 0.03$ & $1.11 \pm 0.03$ & $1.10 \pm 0.03$ & $1.20 \pm 0.04$ & $1.13 \pm 0.01$ \\
& p value* & $\mathbf{0 . 8 0 0}$ & $\mathbf{0 . 1 8 0}$ & $\mathbf{0 . 2 3 8}$ & $\mathbf{0 . 3 3 4}$ & $\mathbf{0 . 3 2 4}$ & $\mathbf{0 . 2 0 4}$ & $\mathbf{0 . 1 4 7}$ & $\mathbf{0 . 5 7 7}$ \\
\multirow{2}{*}{ LDL-C } & Non-carrier & $3.12 \pm 0.02$ & $3.13 \pm 0.03$ & $3.12 \pm 0.02$ & $3.12 \pm 0.02$ & $3.11 \pm 0.02$ & $3.11 \pm 0.02$ & $3.12 \pm 0.02$ & $3.12 \pm 0.02$ \\
& Carrier & $3.11 \pm 0.05$ & $3.11 \pm 0.03$ & $3.11 \pm 0.05$ & $3.10 \pm 0.06$ & $3.17 \pm 0.07$ & $3.12 \pm 0.09$ & $3.10 \pm 0.11$ & $3.10 \pm 0.04$ \\
& p value* & $\mathbf{0 . 9 3 5}$ & $\mathbf{0 . 6 8 8}$ & $\mathbf{0 . 9 5 4}$ & $\mathbf{0 . 8 1 6}$ & $\mathbf{0 . 4 7 6}$ & $\mathbf{0 . 9 2 3}$ & $\mathbf{0 . 8 6 6}$ & $\mathbf{0 . 5 6 8}$ \\
\hline
\end{tabular}

The table shows the mean and standard deviation (SD) of serum lipid levels using univariate Anova (UNIANOVA). A two-tailed (t-test) p-value of 0.05 was considered as statistical significance. The carrier status is defined as a sample which has all five alleles associated with the given haplotype and their count ( $\mathrm{N}$ ) is given. A sample may have more than one haplotype since the gametic phase is unknown.

$\mathrm{N}$ count number; TC total cholesterol; TG triglycerides; LDL-C low density lipoprotein-cholesterol; HDL-C high density lipoprotein-cholesterol.

*t-test p-value of 0.05 was considered as statistical significance.

(95.92\%) with increased TG levels were homozygous for the wild type $\mathrm{M}^{+}$allele. Among the Kuwaiti population, the rare $\mathrm{M}^{-}$allele $(\mathrm{p}=0.031)$ was observed to have a "protective" role exhibiting an 8.8 fold decrease in the risk of high TG levels in individuals homozygous for the rare $\mathrm{M}^{-}$allele. Some of the subjects in the present study with positive family history of hypercholesterolemia $(\mathrm{n}=197)$ also showed a significant association ( $\mathrm{p}=$ $0.046)$ with the rare $M^{-}$allele where there was a higher frequency of heterozygotes $(17.77 \%)$ when compared to those samples with no family history of hypercholesterolemia $(n=409)$. Interestingly, none of these heterozygotes had increased levels of serum TG further supporting the "protective" role of the $\mathrm{M}^{-}$allele. It has been documented that the missense substitution resulting from the loss of the MspI RE site may affect apoB100 protein function; LDL-receptor recognition and binding affinity resulting in abnormal lipid metabolism and levels, and possibly body fat accumulation [23]. The extent of interaction of various mutations in different ethnic groups may also influence the levels, possibly explaining the reason behind conflicting results from different populations.

The inconsistent reports could also be attributed to linkage disequilibrium of the MspI polymorphism with other polymorphisms in genes responsible for lipid metabolism and transport as well as to the diverse biological functions affected by this polymorphism. Haplotype analysis of the five polymorphisms also implicated the same two SNPs indicating the potential effect of
$A P O B$ on serum TG levels. It was observed that carriers for the $A P O B$ haplotype consisting of the $\mathrm{IX}^{-} \mathrm{M}^{-} \mathrm{E}^{+} \mathrm{M}$ (3.11\%) had a significantly $(\mathrm{p}=0.048)$ lower mean serum TG level further supporting the "protective" role for both the insertion allele at the signal peptide and the $\mathrm{M}^{-}$ at the MspI loci on serum TG levels. As observed for the MspI polymorphism in this study, Johansen et al. [9] reported that although there was a possibility of finding few HTG patients with very low risk allele scores as well as few normal individuals with very high risk allele scores, a considerable overlap for a central distribution of risk allele scores could also be found. Since the risk allele TG scores could discriminate between normal individuals and those with the risk of developing HTG based on the extreme values, such identification could aid early intervention.

The results from the present study reflect a genetic predisposition to dyslipidemia in the Kuwaiti population that is unlikely to be attributed to population stratification since there were no statistical differences $(p>$ 0.05) observed between the four ethnic groups that make up the Kuwaiti population. The genotype and allelic distribution for the $A P O B$ polymorphisms in the Kuwaiti population were found to be somewhat different when compared to other populations (Table 8). The allelic frequencies for the signal peptide polymorphism was found to be most similar to that reported for another Arab population, the Tunisian population [21], and somewhat different from some Southeast Asian populations. There are no available 
Table 8 Comparison of the allelic frequencies reported in this study and other studies at the APOB gene locus

\begin{tabular}{|c|c|c|c|c|c|c|c|c|c|c|}
\hline \multirow[t]{2}{*}{ Population } & \multirow[t]{2}{*}{$\mathrm{n}$} & \multicolumn{2}{|c|}{ Ins/Del } & \multicolumn{2}{|l|}{ Xba1 } & \multicolumn{2}{|l|}{ Msp1 } & \multicolumn{2}{|c|}{ EcoR1 } & \multirow[t]{2}{*}{ Reference } \\
\hline & & $\mathrm{I}$ & D & $\mathrm{x}^{-}$ & $\mathrm{X}^{+}$ & $\mathrm{M}^{+}$ & $\mathbf{M}^{-}$ & $\mathrm{R}^{+}$ & $\mathbf{R}^{-}$ & \\
\hline Tunisian & 458 & 0.743 & 0.257 & 0.725 & 0.275 & & & & & Kallel et al. [21] \\
\hline Caucasians & 111 & & & 0.470 & 0.530 & 0.940 & 0.060 & 0.790 & 0.210 & Genest et al. [45] \\
\hline \multirow[t]{2}{*}{ Indian } & 181 & 0.892 & 0.108 & 0.830 & 0.170 & & & 0.900 & 0.100 & Saha et al. [46] \\
\hline & 100 & & & 0.775 & 0.225 & 0.850 & 0.150 & 0.820 & 0.180 & Puri et al. [32] \\
\hline Srilankan & 190 & & & & & 0.981 & 0.019 & 0.969 & 0.031 & Mendis et al. [47] \\
\hline Turkish & 250 & & & 0.690 & 0.310 & & & 0.830 & 0.170 & Duman et al. [36] \\
\hline Danish & 464 & & & 0.51 & 0.49 & 0.913 & 0.087 & 0.83 & 0.17 & Hansen et al. [27] \\
\hline Greek & 90 & & & 0.500 & 0.500 & 0.899 & 0.101 & 0.819 & 0.181 & De Benedictis et al. [48] \\
\hline Mongolians & 110 & 0.909 & 0.091 & 0.936 & 0.064 & 0.991 & 0.009 & 0.950 & 0.050 & Tsunoda et al. [22] \\
\hline Chinese & 288 & 0.793 & 0.207 & 0.909 & 0.091 & 0.928 & 0.072 & 0.929 & 0.071 & Saha et al. [49] \\
\hline Japanese & 1328 & 0.831 & 0.169 & 0.960 & 0.040 & & & 0.934 & 0.066 & Zaman et al. [50] \\
\hline Bulgarians & 147 & 0.793 & 0.207 & 0.568 & 0.432 & 0.959 & 0.041 & 0.816 & 0.184 & Horvath et al. [19] \\
\hline Nigerians & 1222 & 0.749 & 0.251 & 0.843 & 0.158 & & & & & Anderson et al. [33] \\
\hline Kuwait General Population & 795 & 0.774 & 0.226 & 0.735 & 0.265 & 0.933 & 0.067 & 0.894 & 0.106 & Present Study \\
\hline Kuwait HTG & 49 & 0.847 & 0.153 & 0.745 & 0.255 & 0.969 & 0.031 & 0.949 & 0.051 & Present Study \\
\hline Kuwait DYS & 238 & 0.746 & 0.254 & 0.721 & 0.279 & 0.922 & 0.078 & 0.895 & 0.105 & Present Study \\
\hline
\end{tabular}

HTG hypertriglyceridemia; DYS dyslipidemia marked by abnormal LDL-C levels.

frequencies for other Arab ethnic populations for the MspI polymorphism so the frequencies in this study resembled somewhat those reported for Caucasians [45] and those for the Turkish population [36]. The similar frequencies found in the Kuwaiti population, the Tunisians and Turks could be attributed to their common Arab ancestry.

The results from our study agree with studies that correlate genetics, ethnicity and environmental factors with dyslipidemia [21,22]. The combination of these factors could explain the inter-individual variations in lipid levels. Power calculations of $69 \%$ at a $5 \%$ significance for the subpopulation sample size analyzed [43] and a power of $80 \%$ at a $5 \%$ significance in the difference of the mean level of TG in addition to the positive association of the $A P O B$ insertion/deletion and MspI polymorphisms with variation in serum TG levels suggests a strong genetic predisposition to dyslipidemia for the Kuwaiti population. Unlike the present study most reports have indicated an association with LDL-C, and only recently did GWAS population-based studies report an association with TG levels implicating $A P O B$ S4338I polymorphism (rs4635554) with increased risk to HTG [9]. Although the polymorphism detected by GWAS is different from those analyzed in this study, it still implies genetic influence of $A P O B$ on variation in serum lipid levels. Johansen et al. [9] suggested that it is possible that the accumulation of "rare" alleles at different loci, identified and those unidentified may cause TG level variations and dyslipidemia by an unknown molecular mechanism.

\section{Conclusion}

Studies investigating the possible association of various $A P O B$ polymorphisms with specific metabolic disorders or syndromes reported inconsistent findings as well as some conflicting conclusions. The results presented here mainly showed an association of $A P O B$ polymorphisms with variation in serum TG levels among the Kuwaiti population which has not been reported previously. The results may reflect failings in the underlying mechanisms of lipid transport and metabolism, hence leading to abnormal plasma lipid levels. The results supports the need to identify individuals who are at risk of developing HTG and/or dyslipidemia in order to provide them with lifestyle modifications such as personalized nutrition and/or physical activity. Since lipid levels may be genetically controlled, the identification and characterization of genetic variants associated with plasma lipid concentrations can provide useful information related to genotypephenotype relationships [9] and the role of ethnicity. The agreement of this study with others reporting positive association of various $A P O B$ polymorphisms with variation in TG levels and dyslipidemia, as well as the inconsistent frequencies reported for different populations, strongly supports the need for the complete sequencing of the $A P O B$ gene in order to identify known common functional variants and rare "risk" or "protective" alleles. In addition further elucidation of inter-individual and population variations that may affect serum TG and other lipid levels is important. One major limitation of this study was the lack of serum levels of apolipoproteins which could 
have provided further insight into the mechanisms of the significant SNPs identified leading to the effect on the apolipoprotein levels. Finally, lack of association with the 3 of the polymorphisms analyzed (rs693, rs1042031 and the 3'VNTR) could have been due to lack of statistical power as a result of missing data.

\section{Additional files}

\section{Additional file 1: Includes four figures illustrating the banding patterns for the PCR products of the $A P O B$ signal peptide polymorphism (Figure $A$ ) and PCR products digested with the Xbal for the codon 2488 polymorphism (Figure B), Mspl for codon 3611 (Figure C) and EcoRI for codon 4154 (Figure D). The figure legend explains the banding patterns expected and their corresponding genotypes.}

Additional file 2: Includes logistic regression analysis of all five $A P O B$ polymorphisms with TC, HDL and LDL levels. The file includes a total of 3 tables.

Additional file 3: Includes complete data analysis for all the variables analyzed in this study with regards to all five $A P O B$ polymorphisms employing chi-square test and univariate ANOVA. The file includes a total of 10 tables, 2 tables for each polymorphism. The significance values are highlighted and were incorporated into the final manuscript.

\section{Abbreviations}

ANOVA: Analysis of variance; $A P O B$ : Apolipoprotein $B$ gene; $A P O B-$

SP: Apolipoprotein B-signal peptide; BMI: Body mass index; DNA: Deoxyribonucleic acid; DM: Diabetes mellitus; EcoR1: E.coli restriction enzyme I; DNA: Deoxyribonucleic acid; GWAS: Genome wide association studies; FH-HC: Family history of hypercholesterolemia; FH-HTG: Family history of hypertriglyceridemia; HD: Heart disease; HDL-C: High-densitylipoprotein-cholesterol; HDL: High-density lipoprotein; HTG: Hypertriglyceridemia; HWE: Hardy-Weinberg equilibrium; LDL: Low-density lipoprotein; LDL-C: Lowdensity lipoprotein-cholesterol; Mspl: Moraxella sp. type I restriction enzyme; mRNA: Messenger ribonucleic acid; PCR: Polymerase chain reaction; RE: Restriction enzymes; RFLP: Restriction fragment length polymorphism; SPSS: Statistical Package for the Social Sciences; SNPs: Single nucleotide polymorphisms; TC: Total cholesterol; TG: Triglycerides; VLDL: Very low density lipoproteins; VNTR: Variable number tandem repeats; UNI ANOVA: Univariate analysis of variance;

Xbal: Xanthomonas badrii type I restriction enzyme.

\section{Competing interests}

The authors declare that they have no competing interests.

\section{Authors' contributions}

SA prepared the project proposal and study design, supervised the molecular genetic studies and sample collection and phenotypic documentation, supervised the data analysis and drafted the manuscript. BA carried out the molecular genetic techniques and participated in preliminary data analysis and in drafting the manuscript. MA contributed to the study design, participated in the data analysis and actively participated in drafting the manuscript. GE facilitated sample collection and documentation of the clinical and phenotypic data and assisted with the lipid profile analysis. TR supervised the sample collection and lipid profile analysis. All the authors have read and approved the final manuscript.

\section{Acknowledgements}

The authors would like to acknowledge the full support of Kuwait University Research Administration and the General Facility Project (GS 01/02) for the use of the ABI 3130xl Gene Analyzer. The authors extend their deepest appreciation and gratitude to all the participants in this study and the statistical assistance provided by Mr. Sriraman Devrajan at Dasman Diabetes Center, the Power calculations performed by Dr. Ahmed Al-Serri and to the technical staff at Al-Ameri Hospital in Kuwait for their assistance with the blood collection and lipid profile analysis. The PI would also like to acknowledge the valuable review and editing kindly done by Professor Olusegun A. Mojiminiyi.
The authors also extend their sincere appreciation for the English editorial kindly provided by Dr. Martha Thomson.

\section{Financial support}

This research was supported and funded by Kuwait University Research Administration, Project SL05/03.

\section{Author details}

'Department of Biological Sciences, Faculty of Science, Kuwait University, PO Box 5969, SAFAT, 13060 Kuwait City, Kuwait. ${ }^{2}$ Yarmouk Clinic, Ministry of Health, Kuwait City, Kuwait. ${ }^{3}$ Department of Clinical Laboratories, Al-Amiri Hospital, Sharq, Kuwait City, Kuwait.

Received: 23 June 2014 Accepted: 1 October 2014

Published: 8 October 2014

\section{References}

1. Olusi SO, Al-Awadi AM, Abraham M: Baseline population survey data on the prevalence of risk factors for coronary artery disease among Kuwaitis aged 15 years and older. Ann Saudi Med 2003, 23(3-4):162-166.

2. Al Rashdan I, Al Nesef Y: Prevalence of overweight, obesity, and metabolic syndrome among adult Kuwaitis: results from community-based national survey. Angiology 2010, 61(1):42-48.

3. Breslow JL: Genetics of lipoprotein abnormalities associated with coronary artery disease susceptibility. Annu Rev Genet 2000, 34:233-254.

4. Hoton JD, Cohen JC, Hobbs HH: Molecular biology of PCSK9: its role in LDL metabolism. Trends Biochem Sci 2007, 32(2):71-77.

5. Aulchenko YS, Ripatti S, Lindqvist I, Boomsma D, Heid IM, Pramstaller PP, Penninx BW, Janssens AC, Wilson JF, Spector T, Martin NG, Pedersen NL, Kyvik KO, Kaprio J, Hofman A, Freimer NB, Jarvelin MR, Gyllensten U, Campbell H, Rudan I, Johansson A, Marroni F, Hayward C, Vitart V, Jonasson I, Pattaro C, Wright A, Hastie N, Pichler I, Hicks AA, et al: Loci influencing lipid levels and coronary heart disease risk in 16 European population cohorts. Nat Genet 2009, 41(1):47-55.

6. Chasman DI, Paré G, Zee RY, Parker AN, Cook NR, Buring JE, Kwiatkowski DJ, Rose LM, Smith JD, Williams PT, Rieder MJ, Rotter Jl, Nickerson DA, Krauss RM, Miletich JP, Ridker PM: Genetic loci associated with plasma concentration of low-density lipoprotein cholesterol, high-density lipoprotein cholesterol, triglycerides, apolipoprotein A1, and Apolipoprotein B among 6382 white women in genome-wide analysis with replication. Circ Cardiovasc Genet 2008, 1(1):21-30.

7. Deo RC, Reich D, Tandon A, Akylbekova E, Patterson N, Waliszewska A, Kathiresan S, Sarpong D, Taylor HA Jr, Wilson JG: Genetic differences between the determinants of lipid profile phenotypes in African and European Americans: the Jackson Heart Study. Plos Genet 2009, 5(1):e1000342.

8. Boes E, Coassin S, Kollerits B, Heid IM, Kronenberg F: Genetic-epidemiological evidence on genes associated with HDL cholesterol levels: a systematic in-depth review. Exp Gerontol 2009, 44(3):136-160.

9. Johansen $C T$, Kathiresan $S$, Hegele RA: Genetic determinants of plasma triglycerides. J Lipid Res 2011, 52(2):189-206.

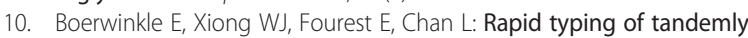
repeated hyper-variable loci by the polymerase chain reaction:Application to the apolipoprotein B 3" hypervariable region. Proc Natl Acad Sci U S A 1989, 86(1):212-216.

11. Blackhart BD, Ludwig EM, Pierotti VR, Caiati L, Onasch MA, Wallis SC, Powell L, Pease R, Knott TJ, Chu ML, Mahley RW, Scott J, McCarthy BJ, Levy Wilson B: Structure of the human apolipoprotein B gene. J Biol Chem 1986, 261(33):15364-15367.

12. Knott TJ, Rall SC, Innerarity TL, Jacobson SF, Urdea MS, Levy Wilson B, Powell LM, Pease RJ, Eddy R, Nakai H, Byers M, Priestly LM, Robertson E, Rall LB, Betsholtz C, Shows TB, Mahley RW, Scott J: Human apolipoprotein B: Structure of carboxyl- terminal domains, sites of gene expression and chromosomal localization. Science 1985, 230(4721):37-43.

13. Huang LS, de Graaf J, Breslow J: ApoB gene Mspl RFLP in exon 26 changes amino acid 3611 from Arg to Gln. J Lipid Res 1988, 29(1):63-67.

14. Ludwig EH, Friedl W, McCarthy BJ: High-resolution analysis of a hypervariable region in the human apolipoprotein B gene. Am J Hum Genet 1989, 45(3):458-464.

15. Pullinger CR, Hennessy LK, Chatterton JE, Liu W, Love JA, Mendel CM, Frost PH, Malloy MJ, Schumaker VN, Kane JP: Familial ligand - defective 
Apolipoprotein B. Identification of a new mutation that decreases LDL receptor binding affinity. J Clin Invest 1995, 95(3):1225-1234.

16. Visvikis $\mathrm{S}$, Chan $\mathrm{L}$, Siest $\mathrm{G}$, Drouin $\mathrm{P}$, Boerwinkle E: An insertion deletion polymorphism in the signal peptide of the human apolipoprotein $B$ gene. Hum Genet 1990, 84(4):373-375.

17. Boerwinkle E, Lee SS, Butler R, Schumaker VN, Chan L: Rapid typing of apolipoprotein B DNA polymorphisms by DNA amplification. Association between Ag epitopes of human apolipoprotein B-100, a signal peptide insertion/deletion polymorphism, and a 3'flanking DNA variable number of tandem repeats polymorphism of the apolipoprotein $B$ gene. Atherosclerosis 1990, 81(3):225-232.

18. Heng CK, Saha N, Low PS: Evolution of the apolipoprotein B gene and coronary artery disease: a study in low and high risk Asians. Ann Hum Genet 1999, 63(Pt 1):45-62.

19. Horvath A, Chorbov V, Zaharova B, Ganev V: Five polymorphisms of the Apolipoprotein B gene in healthy Bulgarians. Hum Biol 2003, 75(1):69-80

20. Ruixing $Y$, Guangqin C, Yong W, Weixiong L, Dezhai Y, Shangling P: Effect of the 3'APOB-VNTR polymorphism on the lipid profiles in the Guangxi Hei Yi Zhuang and Han populations. BMC Med Genet 2007, 8:45.

21. Kallel A, Jemma R, Feki M, El Asmi M, Souissi M, Sanhaji H, Haj-Taieb S, Omar S, Kaabachi N: Xbal polymorphism of apolipoprotein B gene in a Tunisian population: alleles frequencies and relationship with plasma lipid parameters. Annals of Biol Clin (Paris) 2007, 65(3):265-270.

22. Tsunoda K, Harihara S, Tanabe Y, Dashnyam B: Polymorphism of the apolipoprotein B gene and association with plasma lipid and lipoprotein levels in the Mongolian Buryat. Biochem Genet 2012, 50(3-4):249-268.

23. Bentzen J, Jorgensen $T$, Fenger $M$ : The effect of six polymorphisms in the Apolipoprotein B gene on parameters of lipid metabolism in a Danish Population. Clin Genet 2002, 61(2):126-134.

24. Delghandi M, Thangarajah R, Nilsen M, Grimsgaard S, Bonaa KH, Tonstad S, Jorgensen L: DNA polymorphisms of the apolipoprotein B gene (Xbal, EcoRl and Mspl RFLP's) in Norwegians at risk of atherosclerosis and healthy controls. Acta Cardiol 1999, 54(4):215-225.

25. Hu P, Qin YH, Jing CX, Lu L, Hu B, Du PF: Effect of apolipoprotein B polymorphism on body mass index, serum protein and lipid profiles in children of Guangxi. Chinaa Ann Hum Biol 2009, 36(4):411-420.

26. Deka R, Chakraborthy R, Decroo S, Rothhammer F, Barton SA, Ferrell RE: Characteristics of polymorphism at VNTR locus $3^{\prime}$ to the apolipoprotein B gene in five human populations. Am J Hum Genet 1992, 51(6):1325-1333.

27. Hansen PS, Gerdes LU, Kllausen IC, Gregersen N, Faergeman O: Polymorphisms in the Apolipoprotein B-100 Gene Contributes to normal variation in plasma lipids in 464 Danish Men born in 1948. Hum Genet 1993, 91(1):45-50.

28. Choong ML, Sethi SK, Koay ES: Effects of intragenic variability at 3 Polymorphic sites of the apolipoprotein B gene on serum lipids and lipoproteins in a Multiethinic Asian population. Hum Biol 1999, 71(3):381-397.

29. Corbo RM, Scacchi R, Mureddu L, Mulas G, Castrechini S, Rivasi AP: Apolipoprotein B, Apolipoprotein E and angiotensin-converting enzyme polymorphisms in 2 Italian populations at different risk of coronary artery disease and comparison of allele frequencies among European populations. Hum Biol 1999, 71(6):933-945.

30. Alonso S, Fernandez-Fernandez I, Castro A, de Pancorbo MM: Genetic characterization of APOB and DI7S5 AFLP loci in a sample from the Basque country(northern Spain). Hum Biol 1998, 70(3):491-505.

31. Pan JP, Chiang AN, Tai JJ, Wang SP, Chang MS: Restriction fragment length polymorphisms of apolipoprotein B gene in a Chinese population with coronary heart disease. Clin Chem 1995, 41(3):424-429.

32. Puri RD, Tewari S, Sinha N, Ramesh V, Khan F, Singh VP, Agrawal S: Polymorphisms in the apolipoprotein B-100 gene: association with plasma lipid concentration and coronary artery disease. Indian Heart $J$ 2003, 55(1):60-64.

33. Anderson $\mathrm{J}$, Bunker $\mathrm{CH}$, Aston CE, Kamboh Ml: Relationship of two apolipoprotein B polymorphisms with serum lipoprotein and lipid levels in African blacks. Hum Biol 1997, 69(6):793-807.

34. Scartezini M, Zago MA, Chautard- Freire-Maia EA, Pazin-Filho A, Marin-Neto $J A$, Hotta JK, Nascimento AJ, Dos-Santos JE: The X-X-/E + E + genotype of the Xbal/EcoRl polymorphisms of the apolipoprotein $B$ gene as a marker of coronary artery disease in a Brazilian sample. Braz J Med Biol Res 2003, 36(3):369-375

35. Verbenko DA, Pogoda TV, Spitsyn VA, Mikulich AL, Bets LV, Bebyakova NA, Ivanov VP, Abolmasov NN, Pocheshkhova EA, Balanovskaya EV, Tarskaya LA,
Sorensen MV, Limborska SA: Apolipoprotein B 3'-VNTR polymorphism in Eastern European populations. Eur J Hum Genet 2003, 11(6):444-451.

36. Duman BS, Turkoglu C, Akpinar B, Guden M, Vertii A, Cagatay P, Gunay D, Sevim Buyukdevrim A: Genetic variations of the apolipoprotein B gene in Turkish patients with coronary artery disease. Ann Hum Biol 2005, 32(5):620-629.

37. Al-Bustan S, El-Zawahri M, Al-Azmi D, Al Bashir AA: Allele frequencies and molecular genotyping of $\mathrm{ABO}$ blood group system in a Kuwaiti Populations. Int J Hematol 2002, 75(2):147-153.

38. Al-Bustan SA, Alnageeb MA, Annice BG, Ibrhim G, Al-Rubaian J, Ahmed AH Refai TM: Apolipoprotein E genotyping among the healthy Kuwaiti population. Hum Biol 2005, 77(4):487-498.

39. Al-Bustan SA, Alkhalaf M, Al-Rashdan I, Al-Otaibi S, Al-Baker E, Balding D, Alnaqeeb MA: Apolipoprotein $\mathrm{E}, \mathrm{Cl}$ and $\mathrm{B}$ gene polymorphisms in a sample of patients with coronary heart disease in the Kuwaiti population. Med Princ Pract 2009, 18(4):294-299.

40. Miller SA, Dykes DD, Polesky HF: A simple salting-out procedure for extracting DNA from human nucleated cells. Nucleic Acids Res 1988, 16(3):1215.

41. Xu CF, Tikkanen M, Huttunen J, Pietinen P, Butler R, Humphries S, Talmud P: Apolipoprotein B signal peptide insertion/deletion polymorphism is associated with $\mathrm{Ag}$ epitopes and involved in the determination of serum triglyceride levels. J Lipid Res 1990, 31(7):1255-1261.

42. Raymond M, Rousset F: GENEPOP (version 1.2): population genetics software for exact tests and ecumenicism. J Hered 1995, 86:248-249.

43. Faul F, Erdfelder E, Lang AG, Buchner A: G*Power 3: A flexible statistical power analysis program for the social, behavioral, and biomedical sciences. Behav Res Methods 2007, 39(2):175-191.

44. Talmud P, Lins L, Brasseur R: Prediction of signal peptide functional properties: a study of the orientation and angle of insertion of yeast invertase mutants and human apolipoprotein B signal peptide variants. Protein Eng 1996, 9(4):317-321.

45. Genest JJ Jr, Ordovas JM, McNamara JR, Robbins AM, Meade T, Cohn SD, Salem DN, Wilson PW, Masharani U, Frossard PM: DNA polymorphisms of the apolipoprotein B gene in patients with premature coronary artery disease. Atherosclerosis 1990, 82(1-2):7-17.

46. Saha N, Tay JS, Heng CK, Humphries SE: DNA polymorphisms of the apolipoprotein B gene are associated with obesity and serum lipids in healthy Indians in Singapore. Clin Genet 1993, 44(3):113-120.

47. Mendis S, Shepherd J, Packard CJ, Gaffney D: Restriction fragment length polymorphisms in the Apo $B$ gene in relation to coronary heart disease in a southern Asian population. Clin Chim Acta 1991, 196(2-3):107-117.

48. De Benedictis G, Rose G, Mazzei R, Leone O, Crescibene L, Brancati C, Carotenuto L: EcoRI-RFLP of the Apo $B$ gene a study in a sample group from south Italy. Ann Hum Genet 1991, 55(2):103-113.

49. Saha N, Tong MC, Tay JSH, Jeyaseelan K, Humphries SE: DNA polymorphisms of the apolipoprotein B gene in the Chinese coronary artery disease patients. Clin Genet 1992, 42:164-170.

50. Zaman MM, Ikemoto S, Yoshiike N, Date C, Yokoyama T, Tanaka H: Association of apolipoprotein genetic polymorphisms with plasma cholesterol in a Japanese rural population: the Shibata study. Arterioscler Thromb Biol 1997, 17:3495-3504.

doi:10.1186/1476-511X-13-157

Cite this article as: Al-Bustan et al:: Genetic association of $A P O B$ polymorphisms with variation in serum lipid profile among the Kuwait population. Lipids in Health and Disease 2014 13:157. 